OEDIPUS AT THEBES 
This page intentionally left blank 


\section{Bernard Knox}

\section{OEDIPUS AT THEBES}

\section{Sophocles' Tragic Hero and His Time}

Yale University Press

New Haven and London 
Copyright $\odot 1957$ by Yale University.

Copyright $(0)$ renewed 1985 by Bernard Knox.

Preface to the New Edition copyright $(\subset) 1998$ by Yale University.

All rights reserved.

This book may not be reproduced, in whole or in part, including illustrations, in any form (beyond that copying permitted by Sections 107 and 108 of the U.S. Copyright Law and except by reviewers for the public press), without written permission from the publishers.

Library of Congress Cataloging-in-Publication Data

Knox, Bernard MacGregor Walker.

Oedipus at Thebes: Sophocles' tragic hero and his time / Bernard Knox.

p. $\mathrm{cm}$.

Originally published: 1957 . With new preface. Includes bibliographical references and index.

ISBN 978-0-300-07423-9

1. Sophocles. Oedipus Rex. 2. Oedipus (Greek mythology) in literature. 3. Thebes (Greece)-In literature. 4. Heroes in literature. 5. Tragedy I. Title.

$\begin{array}{ll}\text { PA4413.07K55 } 1998 & 97^{-18471} \\ 882 ' .0 \text { I-DC21 } & \text { CIP }\end{array}$

Printed in the United States of America.

A catalogue record for this book is available from the British Library.

The paper in this book meets the guidelines for permanence and durability of the Committee on Production Guidelines for Book Longevity of the Council on Library Resources. 
TO ROWENA WALKER KNOX 
This page intentionally left blank 